http://jurnal.bhmm.ac.id/index.php/jpkm/index

Corresponding Author.

email address : nerserwin.08@gmail.com

Erwin Kurniasih

Received : 16 januari 2020

Revised : 20 februari 2020

Accepted : 2 April 2020

\title{
Lama Terapi Jus Semangka Terhadap Tekanan Darah Lansia Penderita Hipertensi Erwin Kurniasih $^{1}$, Dika Lukitaningtyas ${ }^{2}$
}

${ }^{1,2^{*}}$ Akademi Keperawatan Pemerintah Kabupaten Ngawi

Email: nerserwin.08@gmail.com

\begin{abstract}
ABSTRAK
Hipertensi adalah suatu keadaan tekanan sistolik diatas $140 \mathrm{mmHg}$ dan diastolik diatas $90 \mathrm{mmHg}$. Hipertensi lebih banyak menyerang lansia golongan umur 55 tahun ke atas, seiring bertambahnya usia tekanan darah mengalami peningkatan. Hipertensi dapat menyebabkan komplikasi antara lain kerusakan jantung, stroke, gagal ginjal. Terapi non farmakologi untuk menurunkan tekanan darah salah satunya dengan menggunakan buah semangka yang memiliki kandungan kalium membantu kerja jantung dan menormalkan tekanan darah. Tujuan penelitian ini adalah menganalisis pemberian jus semangka terhadap perubahan tekanan darah pada lansia penderita hipertensi. Penelitian menggunakan metode True Eksperimental dengan Randomized Pre-Post Test Design. Teknik sampling menggunakan Simple Random Sampling dengan jumlah responden sebanyak 36 orang lansia yang dibagi menjadi dua kelompok perlakuan. Hasil analisis uji Wilcoxcon pemberian jus semangka selama 5 hari diperoleh nilai $\mathrm{p}=0,000(<0,05)$ dan pada pemberian jus semangka selama 7 hari diperoleh nilai $\mathrm{p}=0,000(<0,05)$, artinya terdapat perubahan tekanan darah sebelum dan sesudah pemberian jus semangka selama 5 hari dan 7 hari. Hasil uji Mann-Whitney perbandingan dua kelompok diperoleh nilai sistolik $\mathrm{p}=0,490(>0,05)$ dan diastolik $\mathrm{p}=0,732(>0,05)$ artinya tidak terdapat perbedaan efektivitas lama pemberian jus semangka selama 5 hari dan 7 hari terhadap perubahan tekanan darah. Berdasarkan hasil analisis tidak terdapat perbedaan terapi jus semangka terhadap perubahan tekanan darah pada lansia penderita hipertensi. Terapi jus semangka dengan pemberian selama 5 hari dan 7 hari sama-sama dapat menurunkan tekanan darah, dengan terapi jus semangka selama 5 hari sudah mampu menurunkan tekanan darah.
\end{abstract}

Kata kunci : Jus Semangka, Tekanan Darah, Hipertensi, Lansia

ODI : I0.47575/jpkm.vlil.I85 | VOL.IND.I2020 | ISSN: EISSN : 


\begin{abstract}
Hypertension is a condition of systolic pressure above $140 \mathrm{mmHg}$ and diastolic above $90 \mathrm{mmHg}$. Hypertension is more prevalent in elderly people aged 55 years and over, as we age, blood pressure increases. Hypertension can cause complications including heart damage, stroke, kidney failure. Nonpharmacological therapy to reduce blood pressure is one of them by using watermelon which has potassium content in helping the heart work and normalizes blood pressure. The purpose of this study was to analyze the differences in the effectiveness of the administration of watermelon juice for 5 days and 7 days against changes in blood pressure in elderly people with hypertension. The study used the True Experimental method with Randomized Pre-Post Test Design. The sampling technique uses Simple Random Sampling with the number of respondents as many as 36 elderly people divided into two treatment groups. The results of the Wilcoxcon test for administration of watermelon juice for 5 days obtained $p=0,000(<0.05)$ and the watermelon juice supply for 7 days obtained $p=0,000(<0.05)$, meaning that there was a change in blood pressure before and after watermelon juice administration watermelon juice for 5 days and 7 days. The results of the Mann-Whitney test comparing the two groups obtained systolic values $p=0.490(>0.05)$ and diastolic $p=0.732(>0.05)$ meaning that there was no difference in the effectiveness of the watermelon juice for 5 days and 7 days for changes in blood pressure. Based on the results of the analysis there was no difference in the long-term effectiveness of giving watermelon juice for 5 days and 7 days to changes in blood pressure in elderly people with hypertension. This therapy is equally effective in lowering blood pressure, so that more effective consumption of watermelon juice for 5 days has been able to reduce blood pressure.
\end{abstract}

Keywords: Watermelon Juice, Blood Pressure, Hypertension, Elderly

\title{
PENDAHULUAN
}

Hipertensi merupakan penyakit yang berhubungan dengan tekanan darah manusia dimana tekanan sistolik diatas $140 \mathrm{mmHg}$ dan diastolik diatas $90 \mathrm{mmHg}$, dan salah satu penyakit tidak menular yang menjadi masalah kesehatan yang serius. Hipertensi lebih banyak menyerang lansia golongan umur 55 tahun ke atas. Seseorang dikatakan lanjut usia apabila usianya lebih dari 60 tahun (WHO, 2012). Tekanan darah secara alami pada orang dewasa akan mengalami peningkatan seiring bertambahnya usia, secara fisiologis dinding arteri akan mengalami penebalan akibat penumpukan zat kolagen pada lapisan otot, sehingga pembuluh darah akan menyempit dan kaku, hal tersebut akan menyebabkan tekanan darah menjadi tinggi (Sari, Restipa, dan Putri, 2017).

Hipertensi masih menjadi tantangan besar di Indonesia. Prevalensi hipertensi di seluruh dunia, diperkirakan sekitar 15-20\%. Data WHO (World Health Organization) tahun 2015 menunjukkan sekitar 1,13 miliar orang di dunia menderita hipertensi. Hipertensi lebih banyak menyerang usia lansia, data dari National Health Documentation di USA menemukan prevalensi hipertensi $15-27 \%$ pada orang-orang berusia 65 tahun keatas. Di Indonesia, berdasarkan data Survei Indikator Kesehatan Nasional (Sirkesnas) tahun 2016 prevalensi hipertensi pada penduduk usia 18 tahun ke atas sebesar 32,4\%. Data dari Profil Kesehatan tahun 2016 di Provinsi Jawa Timur sebesar 13,47\%. Prevelensi hipertensi berdasarkan data dari dinas kesehatan Kabupaten Madiun tahun 2019 sebesar 11,71\%. Posyandu lansia Desa Kertobanyon data pada bulan Januari 2019 lansia yang menderita hipertensi sebanyak 38 orang.

Penelitian terkait buah semangka sudah banyak dilakukan oleh peneliti-peneliti lain, dan terbukti buah semangka dapatmempengaruhi perubahan tekanan darah pada penderita hipertensi tanpa efek samping yang merugikan. Salah satunya penelitian oleh Maya Fadlilah (2016) memberikan terapi jus semangka satu cangkir potong semangka dadu (152 gram) dengan intensitas waktu 5 hari berturut turut dapat mempengaruhi perubahan tekanan darah. Penelitian oleh Nova dan Vivi (2014) dengan memberikan jus semangka 200 gram setiap harinya dengan intensitas waktu selama 7 hari berturutturut, hal ini membuktikan terjadi penurunan tekanan darah sistolik dan diastolik. Perbandingan lama pemberian jus semangka antara 5 hari dan 7 hari ini perlu dibandingkan, untuk mengetahui perbedaan efektivitas lama pemberian jus semangka agar lebih efisien. Pemberian jus semangka ini akan diberikan dengan kadar 200 gram buah semangka yang di jus. 
Daging buah semangka mengandung air sebanyak 93.4\%, protein $0.5 \%$, karbohidrat $5.3 \%$, lemak $0.1 \%$, serat $0.2 \%$, berbagai macam vitamin (A, B, dan $\mathrm{C}$ ), antioksidan seperti asam amino (citrulline dan arginine) mampu memproduksi nitrogen monoksida (NO) yaitu molekul gas yang dapat membantu merelaksasikan pembuluh darah, asam asetat, asam malat, asam folat, likopen, karoten, bromin, kalium, silvit, lisin, fruktosa, dekstrosa, dan sukrosa. Kandungan dalam semangka yang berkhasiat menurunkan tekanan darah tinggi yaitu kalium, vitamin $\mathrm{C}$, karbohidrat dan likopen yang berfungsi untuk meningkatkan kerja jantung serta citrulline yang mampu mendorong aliran darah ke seluruh bagian tubuh dan vitamin B6 yang dapat merangsang hormon dalam otak untuk mengatasi kecemasan. Kalium yang cukup tinggi juga berperan sebagai diuretik alami yang dapat membantu kerja jantung dan menurunkan tekanan darah Shanti (2016).

Penurunan tekanan darah sistol dengan pemberian jus semangka berhubungan dengan kandungan kalium, flavanoid, apigenin, vitamin C, vitamin K, fitosterol. Kandungan tersebut dapat mempengaruhi vasodilatasi sehingga darah dapat mengalir dengan lebih lancar dan membuat tekanan darah menurun. Penurunan tekanan darah diastol dengan pemberian jus semangka berhubungan dengan kandungan potassium, beta karoten, dan kalium yang terdapat dalam buah semangka, kalium yang ada dalam buah semangka dapat memicu kehilangan natrium melalui urin sehingga dapat menormalkan tekanan darah (Maya Fadlilah, 2016)

Tujuan penelitian ini adalah menganalisis perbedaan efektivitas lama pemberian jus semangka selama 5 hari dan 7 hari terhadap perubahan tekanan darah pada lansia penderita hipertensi.

Pembuatan jus dari buah segar sangatlah mudah dan harganya terjangkau sehingga dapat digunakan sebagai alternatif untuk mengatasi tekanan darah tinggi, dibandingkan dengan obat-obatan dari bahan kimia yang apabila dikonsumsi jangka panjang dapat menyebabkan efek samping antara lain dehidrasi, hipokalemi, hiponatremia, gagal jantung (Udjianti, 2010). Selain menurunkan tekanan darah semangka juga dapat menetralkan tekanan darah sehingga pengkonsumsi jus semangka tidak akan mengalami penurunan tekanan darah secara terus menerus, sehingga semangka aman dikonsumsi tanpa rasa khawatir akan membuat drop tekanan darah, artinya tekanan darah akan tetap stabil.

\section{METODE PENELITIAN}

Desain penelitian ini menggunakan True experimental dengan rancangan Randomized pretestposttest design. Populasi dalam penelitian ini sebanyak 38 lansia penderita hipertensi di Posyandu Lansia Desa Kertobanyon Kecamatan Geger Kabupaten Madiun, dan sampel yang diambil sebanyak 36 responden. Teknik sampling menggunakan Simple Random Sampling yang dibagi menjadi dua kelompok perlakuan, setiap kelompok sebanyak 18 responden. Variabel Independent penelitian ini yaitu jus semangka dan variabel dependent yaitu tekanan darah. Setelah data terkumpul dilakukan uji normalitas dan didapatkan hasil data berdistribusi tidak normal maka uji statistik yang digunakan yaitu Uji Wilcoxcon Test untuk mengetahui pengaruh pemberian jus semangka selama 5 hari dan 7 hari terhadap perubahan tekanan darah dan Uji Mann- Whitney untuk mengetahui perbedaan efektivitas antara pemberian jus semangka selama 5 hari dan 7 hari terhadap perubahan tekanan darah.

\section{HASIL DAN PEMBAHASAN}

Data umum menyajikan karakteristik responden berdasarkan jenis kelamin, karakretistik berdasarkan usia, dan karakteristik berdasarkan pekerjaan.

\section{Tabel 1}

Karakteristik Responden Penderita Hipertensi Berdasarkan Jenis Kelamin Di Desa Kertobanyon Kecamatan Geger Kabupaten Madiun tahun 2020

\begin{tabular}{lcc}
\hline \multicolumn{1}{c}{ Jenis Kelamin } & $\begin{array}{c}\text { Frekuensi } \\
\text { (f) }\end{array}$ & $\begin{array}{c}\text { Prosentase } \\
\text { (\%) }\end{array}$ \\
\hline Laki-Laki & 7 & $19,4 \%$ \\
Perempuan & 29 & $80,6 \%$ \\
Total & 36 & $100 \%$ \\
\hline
\end{tabular}

Sumber: Data Primer Responden, 2020 
Berdasarkan tabel 1 dapat diketahui bahwa dari 2 kelompok tersebut berjumlah 36 responden, frekuensi jenis kelamin perempuan lebih banyak dibandingkan jenis kelamin laki-laki yaitu masingmasing 29 responden $(80,6 \%)$ dan 7 responden $(19,4 \%)$.

\section{Tabel 2}

Karakteristik Responden Penderita Hipertensi Berdasarkan Usia

Di Desa Kertobanyon Kecamatan Geger Kabupaten Madiun tahun 2020

\begin{tabular}{lcc}
\hline & Kategori & Usia Responden \\
\hline Jumlah & 36 \\
Mean & 65 \\
Minimal & 60 \\
Maksimal & 77 \\
Standart Deviasi & 4,447 \\
\hline
\end{tabular}

Sumber: Data Primer Responden, 2020

Berdasarkan tabel 2 dapat diketahui bahwa dari 2 kelompok tersebut jumlah responden 36 dengan rata-rata usia responden yaitu 65 tahun dengan usia minimal responden 60 tahun dan usia maksimal responden 77 tahun.

Tabel 3

Karakteristik Responden Penderita Hipertensi Berdasarkan Pekerjaan

Di Desa Kertobanyon Kecamatan Geger Kabupaten Madiun Tahun 2020

\begin{tabular}{lcc}
\hline \multicolumn{1}{c}{ Pekerjaan } & (f) & $\mathbf{( \% )}$ \\
\hline Tidak Bekerja & 20 & $55,6 \%$ \\
Pensiunan & 2 & $5,6 \%$ \\
Pedagang & 3 & $8,3 \%$ \\
Petani & 6 & $16,7 \%$ \\
Swasta & 5 & $13,9 \%$ \\
Total & 36 & $100 \%$ \\
\hline
\end{tabular}

Sumber: Data Primer Responden, 2020

Berdasarkan tabel 3 dapat diketahui bahwa dari 2 kelompok tersebut jumlah responden 36, frekuensi pekerjaan berurutan dari yang terbesarke terkecil adalah tidak bekerja sebanyak 20 orang $(55,6 \%)$, petani 6 orang $(16,7 \%)$, swasta 5 orang $(13,9 \%)$, pedagang 3 orang $(8,3 \%)$, dan pensiunan sebanyak 2 orang $(5,6 \%)$.

Data Khusus responden menyajikan hasil pengolahan data yaitu perbandingan tekanan darah sebelum dan sesudah terapi pemberian jus semangka.

Tabel 4

Perbandingan Tekanan Darah Sistolik Dan Diastolik Sebelum Dan Sesudah Pemberian Jus Semangka Selama 5 Hari Di Posyandu Lansia Desa Kertobanyon Kecamatan Geger Kabupaten Madiun Tahun 2020

\begin{tabular}{ccccc}
\hline \multirow{2}{*}{ Kategori } & \multicolumn{3}{c}{ Tekanan Darah } \\
\cline { 2 - 5 } & \multicolumn{2}{c}{ Sistolik } & \multicolumn{2}{c}{ Diastolik } \\
\cline { 2 - 5 } & 152,22 & 126,67 & 92,22 & 83,33 \\
Mean & 140 & 120 & 80 & 80 \\
Minimal & 180 & 140 & 100 & 90 \\
Maksimal & 11,144 & 7,670 & 8,085 & 4,851 \\
Standart Deviasi & & 0,000 & & \multicolumn{2}{c}{0,000} \\
$p$ (Asymp. Sig. 2-tailed) & &
\end{tabular}

Sumber: Hasil Olah Data Responden Di Posyandu Lansia Desa Kertobanyon, 2020 
Berdasarkan tabel 4 dapat diketahui tekanan darah pada kelompok pemberian jus semangka selama 5 hari diperoleh rata-rata sistolik pre sebesar 152,22 $\mathrm{mmHg}(\mathrm{SD} 11,144)$ dan post sistolik $126,67 \mathrm{mmHg}(\mathrm{SD} 7,670)$. Rata-rata diastolik pre sebesar 92,22 $\mathrm{mmHg}(\mathrm{SD} 8,085)$ dan post 83,33 $\mathrm{mmHg}$ (SD 4,851). Rata- rata selisih tekanan darah sistolik sebesar 25,56 $\mathrm{mmHg}$ dan diastolik 8,89 mmHg. Hasil uji Wilcoxon menunjukkan nilai p (Asymp. Sig. 2-tailed) sebesar 0.000 lebih kecil dari $\alpha$ $(0,05)$, artinya ada perbedaan yang signifikan antara tekanan darah sebelum dan sesudah diberi jus semangka selama 5 hari.

Hasil penelitian menunjukkan tekanan darah sebelum dan sesudah diberikan jus semangka selama 5 hari terdapat perbedaan rerata tekanan darah sistolik dan diastolik, dengan hasil selisih tekanan darah sistolik sebesar $25,56 \mathrm{mmHg}$ dan tekanan darah diastolik sebesar $8,89 \mathrm{mmHg}$. Penelitian ini sejalan dengan hasil penelitian dari Maya Fadlilah (2016) yang berjudul Pengaruh Pemberian Jus Semangka Terhadap Tekanan Darah Pada Lansia Penderita Hipertensi Di Panti Tresna Werdha Teratai Palembang, didapatkan hasil nilai signifikan untuk penurunan tekanan darah baik sistolik maupun diastolik, artinya ada pengaruh pemberian jus semangka terhadap perubahan tekanan darah.

\section{Tabel 5}

Perbandingan Tekanan Darah Sistolik Dan Diastolik Sebelum Dan Sesudah Pemberian Jus Semangka Selama 7 Hari Di Posyandu Lansia Desa Kertobanyon Kecamatan Geger Kabupaten Madiun Tahun 2020

\begin{tabular}{|c|c|c|c|c|}
\hline \multirow{3}{*}{ Kategori } & \multicolumn{4}{|c|}{ Tekanan Darah } \\
\hline & \multicolumn{2}{|c|}{ Sistolik } & \multicolumn{2}{|c|}{ Diastolik } \\
\hline & Pre & Post & Pre & Post \\
\hline Mean & 150,00 & 125,00 & 92,78 & 83,89 \\
\hline Minimal & 140 & 120 & 80 & 80 \\
\hline Maksimal & 180 & 140 & 100 & 90 \\
\hline Standart Deviasi & 11,376 & 7,071 & 6,691 & 5,016 \\
\hline$p$ (Asymp. Sig. 2-tailed) & \multicolumn{2}{|c|}{0,000} & \multicolumn{2}{|c|}{0,000} \\
\hline
\end{tabular}

Sumber: Hasil Olah Data Responden Di Posyandu Lansia Desa Kertobanyon, 2020

Berdasarkan tabel 6 dapat diketahui tekanan darah pada kelompok pemberian jus semangka selama 7 hari diperoleh rata-rata sistolik pre sebesar 150,00 $\mathrm{mmHg}$ (SD 11,376) dan post sistolik $125,00 \mathrm{mmHg}$ (SD 7,071). Rata-rata diastolik pre sebesar 92,78 $\mathrm{mmHg}$ (SD 6,691) dan post 83,89 $\mathrm{mmHg}$ (SD 5,016). Rata- rata selisih tekanan darah sistolik sebesar 25,00 $\mathrm{mmHg}$ dan diastolik 8,89 mmHg. Hasil uji Wilcoxon menunjukkan nilai p (Asymp. Sig. 2-tailed) sebesar 0.000 lebih kecil dari $\alpha$ $(0,05)$, artinya ada perbedaan yang signifikan antara tekanan darah sebelum dan sesudah diberi jus semangka selama 7 hari.

Hasil penelitian menunjukkan tekanan darah sebelum dan sesudah diberikan jus semangka selama 7 hari terdapat perbedaan rerata tekanan darah sistolik dan diastolik, dengan hasil selisih tekanan darah sistolik sebesar 25,00 $\mathrm{mmHg}$ dan tekanan darah diastolik sebesar 8,89 mmHg. Penelitian ini sejalan dengan penelitian yang dilakukan oleh Nova dan Vivi (2014) yang berjudul Pengaruh Pemberian Jus Semangka (Cilitrus Vulgaris Schrad) Terhadap Penurunan Tekanan Darah Lansia Dengan Riwayat Hipertensi Di Kota Padang, dapat disimpulkan ada perbedaan yang bermakna antara tekanan darah sistolik dan diastolik sebelum dan sesudah pemberian jus semangka. 
Tabel 6

Perbandingan Tekanan Darah Sistolik Dan Diastolik Setelah

Pemberian Jus Semangka Selama 5 Hari Dan 7 Hari Di Posyandu Lansia Desa Kertobanyon Kecamatan Geger Kabupaten Madiun Tahun 2020

\begin{tabular}{lcccc}
\hline \multirow{2}{*}{ Kategori } & \multicolumn{2}{c}{$\begin{array}{c}\text { Pemberian Jus Semangka } \\
\text { Selama 5 Hari }\end{array}$} & \multicolumn{2}{c}{$\begin{array}{c}\text { Pemberian Jus Semangka } \\
\text { Selama 7 Hari }\end{array}$} \\
\cline { 2 - 5 } & \multicolumn{2}{c}{ Sistol } & Diastol & \multicolumn{2}{c}{ Sistol } & Diastol \\
\hline Mean & 126,67 & 83,33 & 125,00 & 83,89 \\
Minimal & 120 & 80 & 120 & 80 \\
Maksimal & 140 & 90 & 140 & 90 \\
Standart Deviasi & 7,670 & 4,851 & 7,071 & 5,016 \\
$p$ value & \multicolumn{2}{c}{ Sistol 0,490} & \multicolumn{2}{c}{ Diastol 0,732} \\
\hline
\end{tabular}

Sumber: Hasil Olah Data Responden Di Posyandu Lansia Desa Kertobanyon, 2020

Berdasarkan tabel 6 pada kelompok pemberian jus semangka selama 5 hari dapat diketahui tekanan darah rata-rata sistolik $126,67 \mathrm{mmHg}$ dan rata-rata diastolik 83,33. Pada kelompok pemberian jus semangka selama 7 hari dapat diketahui tekanan darah rata-rata sistolik 125,00 $\mathrm{mmHg}$ dan rata-rata diastolik 83,89 mmHg. Hasil uji Maan-Whitney U Test didapatkan nilai p (Asymp. Sig. 2-tailed) sistolik sebesar 0.490 lebih besar dari $\alpha(0,05)$ dan diastolik sebesar 0.732 lebih besar dari $\alpha(0,05)$, artinya tidak ada perbedaan efektivitas lama pemberian jus semangka selama 5 hari dan 7 hari terhadap perubahan tekanan darah.

Berdasarkan hasil penelitian pemberian jus semangka selama 5 hari dan 7 hari yang sudah diberikan kepada responden menunjukkan hasil uji Mann-Whitney terhadap perbedaan efektivitas lama pemberian jus semangka didapatkan nilai $\mathrm{p}$ sistolik sebesar 0,490 lebih besar dari $\alpha(0,05)$ dan nilai $\mathrm{p}$ diastolik sebesar 0.732 lebih besar dari $\alpha(0,05)$, sehingga dapat disimpulkan bahwa tidak ada perbedaan efektivitas lama pemberian jus semangka selama 5 hari dan 7 hari terhadap perubahan tekanan darah.

Semangka merupakan buah yang dapat menurunkan tekanan darah. Kandungan buah semangka yang dapat mempengaruhi tekanan darah antara lain kalium, likopen, dan vitamin B6. Kandungan kalium sendiri dapat mempengaruhi keseimbangan natrium yang akan mengikat air pada sistem renin terjadilah diuretik dengan membuang kelebihan garam dalam air melalui urin. Jumlah garam terutama natrium $(\mathrm{Na})$ yang akan diserap kembali oleh ginjal akan dikurangi dan $(\mathrm{Na})$ tersebut akan ikut membawa cairan yang ada dalam darah sehingga produksi urin bertambah, hal ini sangat baik bagi tubuh karena racun dan kadar natrium berlebih yang ada dalam tubuh dibuang melalui urin, hal ini mempengaruhi penurunan curah jantung dan dapat menurunkan tekanan darah. Likopen sebagai anti oksidan berupa L-Citrulline dan L-Arginine (sejenis asam amino citrulline digunakan untuk memproduksi asam amino arginine digunakan sel sel pelapis pembuluh darah untuk membuat nitrogen monoksida) yang dapat melemaskan pembuluh darah (mencegah endapan lemak) dan mencegah terjadinya penyakit jantung, hal ini dapat menyebabkan vasodilatsi pembuluh darah. Vitamin B6 yang merangsang hormon dalam otak (serotonin, dopamine, neropinephrine) yang dapat melemaskan pembuluh darah dan menyebabkan vasodilatasi pembuluh darah. Pembuluh darah yang mengalami vasodilatasi yang disebabkan oleh kandungan buah semangka tersebut dapat mempengaruhi penurunan tahanan perifer yaitu pada tekanan arteri-vena akibat vasodilatasi pembuluh darah. Buah semangka juga memiliki kandungan yang bermanfaat dalam mengontrol tekanan darah, seperti serat, kalium, air, vitamin C, vitamin A (karetenoid), vitamin B6, vitamin K, licopein dan asam amino sitrulin Pebriyanti (2016).

Tekanan darah sistolik merupakan tekanan darah pada saat terjadi kontraksi otot jantung atau saat jantung memompa darah ke pembuluh nadi. Penurunan tekanan darah sistol dengan pemberian jus semangka berhubungan dengan kandungan kalium, flavanoid, apigenin, vitamin C, vitamin K, fitosterol. Kandungan tersebut dapat mempengaruhi vasodilatasi sehingga darah dapat mengalir dengan lebih lancar dan membuat tekanan darah menurun. Tekanan darah diastolik merupakan tekanan darah pada saat jantung sedang relaksasi atau istirahat. 
Penurunan tekanan darah diastol dengan pemberian jus semangka berhubungan dengan kandungan potassium, beta karoten, dan kalium yang terdapat dalam buah semangka, kalium yang ada dalam buah semangka dapat memicu kehilangan natrium melalui urin sehingga dapat menormalkan tekanan darah. Kandungan kalium pada semangka mampu menurunkan efek natrium sehingga tekanan darah menurun. Kalium atau pottasium berfungsi untuk menjaga kekentalan dan menstabilkan darah agar tetap stabil. Hubungan terbalik antara kalium dan natrium inilah yang menjelaskan penurunan tekanan darah baik sistolik maupun diastolik Pebriyanti (2016).

Semangka dapat menurunkan tekanan darah dengan cara mencegah pengerasan dinding arteri maupun pembuluh vena, menyebabkan vasodilatasi yang dapat melebarkan pembuluh darah, sehingga darah dapat mengalir lebih lancar dan terjadi penurunan retensi perifer, sebagai anti oksidan dan efek diuretik. Jus semangka dibuat dengan cara dihancurkan dengan blander hingga halus. Buah semangka yang digunakan sebanyak 200 gram dan $50 \mathrm{ml}$ air putih untuk setiap respondennya. Menurut Julia Greer dalam Pebriyanti (2016), rasa manis pada buah semangka disebabkan oleh fruktosa kira-kira 30$40 \%$ orang tidak mampu menyerap fruktosa seluruhnya dalam keadaan perut kosong, sehingga dapat menyebabkan perut kembung, gas berlebih, serta diare, maka dari itu untuk menghindari hal tersebut jus semangka diberikan setelah makan pagi.

Konsumsi buah agar dapat dirasakan manfaatnya secara efektif, yaitu bisa dengan cara membuat jus. Meskipun harus lebih dahulu mempersiapkan alat pembuat jus dan bahan campuran lainnya, tekstur jus yang halus akan lebih mudah dan cepat untuk dikonsumsi oleh lansia apalagi pada lansia biasanya jumlah gigi sudah tidak lengkap.

Kandungan buah semangka yang diberikan pada kedua kelompok diberikan dengan porsi dan cara yang sama, yaitu buah semangka sebanyak 200 gram dan $50 \mathrm{ml}$ air putih kemudian dijus dengan blander hingga halus. Menurut Nova (2014), rasa manis pada buah semangka disebabkan oleh fruktosa kira-kira 30- $40 \%$ orang tidak mampu menyerap fruktosa seluruhnya dalam keadaan perut kosong, sehingga dapat menyebabkan perut kembung, gas berlebih, serta diare, maka dari itu untuk menghindari hal tersebut jus semangka diberikan setelah makan pagi. Lama pemberian jus semangka inilah yang membedakan dari kedua kelompok terapi, yaitu dengan lama pemberian jus semangka selama 5 hari dan 7 hari. Ternyata jus semangka yang diberikan selama 5 hari dan 7 hari sama- sama efektif dalam menurunkan tekanan darah, untuk lebih efektifnya konsumsi jus semangka selama 5 hari berturut-turut sudah mampu menurunkan tekanan darah.

\section{KESIMPULAN}

Berdasarkan hasil penelitian terjadi perubahan tekanan darah sistolik dan diastolik sebelum dan sesudah diberikan jus semangka selama 5 hari dan atau 7 hari pada lansia penderita hipertensi dan Tidak ada perbedaan efektivitas lama pemberian jus semangka selama 5 hari dan 7 hari terhadap perubahan tekanan darah sistolik dan diastolik pada lansia penderita hipertensi. Menjadikan terapi jus semangka sebagai salah satu pengobatan hipertensi secara non farmakologi. 


\section{DAFTAR PUSTAKA}

Dinas Kesehatan Kabupaten Madiun. 2016. Tersedia dalam http:/www.dinkes.madiunkab.go.id (Diakses 10 Desember 2018).

Depkes RI. 2010. Pedoman Teknis Penemuan Dan Tatalaksana Penyakit Hipertensi. Jakarta : Direktorat Pengendalian Penyakit Tidak Menular Direktorat Jenderal PP \& PL.

F. Nova dan S.Vivi, S. 2014. Pengaruh Pemberian Jus Semangka (Clitrus Vulgaris Schard) Terhadap Penurunan Darah Lansia Dengan Riwayat Hipertensi Di Kota Padang. Jurnal Padang: STIKes Mercubaktijaya Padang.

Fadlilah, Maya. 2016. Pengaruh Pemberian Jus Semangka Terhadap Tekanan Darah Pada Lansia Penderita Hipertensi Di Panti Tresna Werdha Teratai Palembang. Palembang: STIKes Muhammadiyah Palembang. Jurnal Volume 4. Nomor 1, Juni 2016.

Pebriyanti, Widya dan Wibowo, Adityo. 2016. Pengaruh Konsumsi Semangka ( Citrullus Vulgaris) Untuk Menurunkan Tekanan Darah Pada Penderita Hipertensi. Lampung: Fakultas Kedokteran Universitas Lampung. Jurnal Majorrity Volume 5 Nomor 5 Desember 2016.

Potter \& Perry. 2005. Buku Ajar Fundamental Keperawatan : Konsep, Proses, dan Praktik. Edisi 4. Jakarta:EGC.

Profil Kesehatan Indonesia Kementrian Kesehatan. 2016. Profil Kesehatan Indonesia 2016. Tersedia dalam http://www.depkes.go.id (Diakses 10 Desember 2018).

Safitri, Nedya. 2018. Lanjut Usia. Tersedia dalam http://yankes.kemkes.go.id/read-masalahkesehatan-pada-lansia-4884.html(Diakses 29 Januari 2019).

Sari, Restipa, dan Putri. 2017. Pengaruh Pemberian Jus Semangka Terhadap Penurunan Tekanan Darah Pada Lansia Penderita Hipertensi Di Wilayah Kerja Puskesmas Lubuk Buaya Padang Tahun 2017. Jurnal Ilmu Kesehatan (JIK) Oktober, Volume 1 Nomor 1 P-ISSN: 2597-8594.

Setyawati, Maryati, dan Mubarak. 2017. Pengaruh Pemberian Jus Semangka Terhadap Perubahan Tekanan Darah Pada Penderita Hipertensi. Jombang: STIKes Pemkab Jombang. Jurnal Vol 3 No 2.

Shanti, Ni Made dan Zuraida,Reni. 2016. Pengaruh Pemberian Jus Semangka Terhadap Penurunan Tekanan Darah. Lampung: Fakultas Kedokteran Universitas Lampung. Jurnal Majorrity Volume 5 Nomor 4 Oktober 2016.

Sirkesnas. 2016. Prevelensi Hipertensi. Tersedia dalam http://www.labdata.litbang.depkes.go.id (Diakses 12 Desember 2018).

Udjianti W.J. 2010. Keperawatan kardiovaskuler. Jakarta: Salemba Medika.

World Health Organization. 2012. Global NCD Target Reduce High Blood Pressure. 2012. Tersedia dalam www.who.int/beat-ncds/take-action/policy-brief-reducehigh-blood-pressure (Diakses 12 Desember 2018) 